\title{
SUPPORT OF INFORMATICS TEACHING BY THE AID OF GAMIFICATION ELEMENTS
}

\section{[PODPORA VYUCOVANIA INFORMATIKY POMOCOU GAMIFIKACNYCH PRVKOV]}

\author{
Nika Klimova
}

doi: 10.18355/PG.2019.8.1.14

\begin{abstract}
There are a number of classroom management systems on the market. One of them is Classcraft, which also contains gamification elements. In the paper we describe the implementation and evaluate the experience of using Classcraft in teaching informatics. The implementation took place in the school year 2017/2018 in the 5th year at the primary school with the kindergarten J. Bakossa in the subject Informatics. This school year is being implemented in the 6th and 8th grades, but already in the paid version.
\end{abstract}

\section{Key words}

classcraft, gamification, computer science teaching, classroom management system

\section{Anotácia}

$\mathrm{Na}$ trhu sa nachádza značné množstvo softvérov zameraných na manažment triedy (classroom management system). Jedným z nich je Classcraft, ktorý v sebe obsahuje aj gamifikačné prvky. V príspevku opisujeme implementáciu a hodnotíme skúsenosti $\mathrm{z}$ používania systému Classcraft vo vyučovaní informatiky. Implementácia prebehla pilotne v školskom roku 2017/2018 v 5. ročníku na ZŠ s MŠ J. Bakossa v predmete informatika. V tomto školskom roku prebieha implementácia do 6. a 8. ročníka, ale už v platenej verzii.

\section{Kl’účové slová}

classcraft, gamifikácia, vyučovanie informatiky, classroom management system

\section{1 Úvod}

Digitálna éra mení spôsob, akým l’udia riešia problémy, komunikujú, takisto ako myslia alebo sa učia (Michaličková a Lovászová, 2014). Na svete už máme generáciu l'udí, ktorá vyrástla s novými mediálnymi technológiami (Vrabec, 2010). Takíto l'udia sa označujú ako iGeneration, Net-Gen či na Slovensku zaužívaný pojem digitálni domorodci. Opakom sú digitálni pristahovalci, ktorí sa do tejto doby nenarodili. Preto sa $\mathrm{v}$ dnešnej dobe vyvíjajú nové prvky vo vyučovacom procese, aby boli čo najviac prispôsobené potrebám dnešných žiakov. Jedným z prvkov je aj gamifikácia 
vo vyučovaní, ktorá sa dá dosiahnut' napríklad prostredníctvom systému Classcraft.

\section{Gamifikácia}

Gamifikácia pochádza z ang. g. Gamification: gam(e) + -ification, sloveso „to gamify“ a znamená koncept využívajúci herné myslenie/dizajn na neherný kontext/aplikácie za účelom zábavy a zapojenia používatel'a (Jarábek, 2013). Využíva sa v rôznych odvetviach, napr. v armáde, v investovaní či vzdelávaní. Za všetkým treba hl'adat' prirodzenú túžbu dosiahnut' úspech, sút'ažit', sebavyjadrit' sa a iné. Existuje niekol'ko mechanizmov, ktorými sa gamifikácia vyznačuje:

- úspechy (odmeňovanie napr. odznakmi),

- behavioral momentum (tendencia hráčov pokračovat' v niečom, čo momentálne robia),

- blažená produktivita (t’ažká práca hraním robí človeka št’astnejším ako keby relaxoval),

- bonusy (odmena za dokončenie problému),

- teória kaskádových informácií (informácie zverejňované v malých dávkach),

- odpočítavanie (určitý čas na určitú úlohu),

- kolaborácia spoločnosti (herná dynamika, kde je viacero l’udí riešiacich rovnaký problém),

- objavovanie (kde ako úspech prichádza prekvapenie),

- epický význam (viera, že hráč pracuje na niečom významnom a väčšom ako oni sami),

- $\quad$ free lunch (pocit, že hráč dostáva niečo zadarmo) a iné.

\subsection{Prostredie Classcraft a jeho možnosti}

Prostredie je určené pre žiakov, graficky sa približuje práve mladej generácii. Využíva mnohé prvky gamifikácie, ako napr. úspechy, bonusy, teóriu kaskádových informácií a iné. Učitel'ské prostredie (obr. 1) je podobné, ale s inými funkcionalitami než študentské. Učitel' si môže vytvorit' triedu, je tzv. Strážcom hry - nemá avatara, ale ovláda a pridáva body všetkým v skupine.

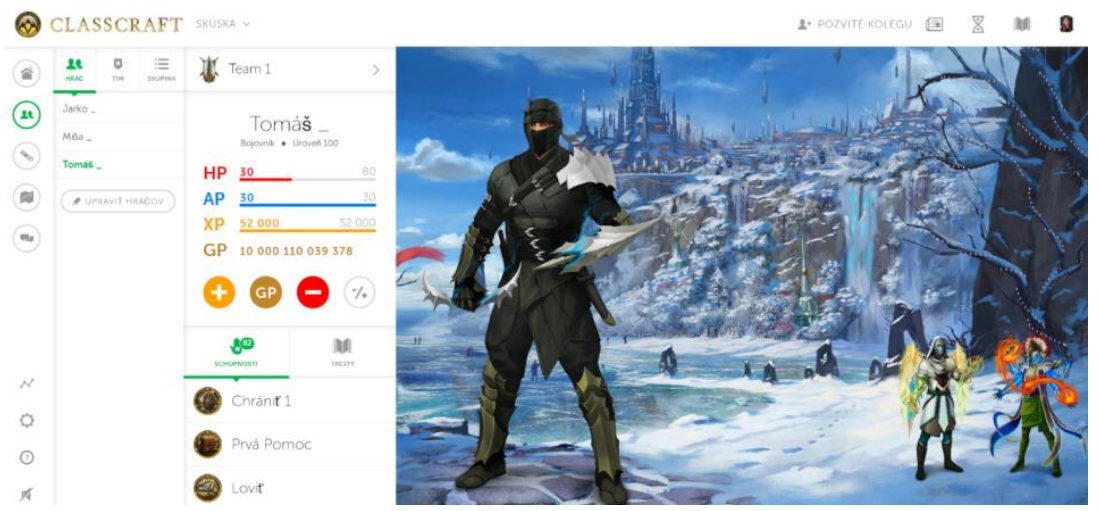

Obrázok 1 Ucitel'ské prostredie Classcraft

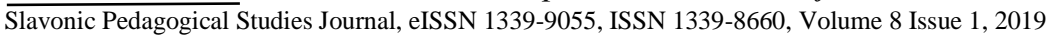


Hlavná ovládacia lišta sa nachádza vl’avo, ktorá zahrňuje tzv. hlavné prostredie, kde sa pridávajú alebo odoberajú body, napr. za spoluprácu, za splnenú úlohu a ostatné - učitel'om dané - úspechy, príp. neúspechy (vyrušovanie na hodine).

$\mathrm{Na}$ lište sa nachádzajú aj skupinové nástroje, ktoré sa dajú využit' pri vytváraní klímy triedy a zhernení vyučovacieho procesu, úlohy, ktoré pozostávajú zo svetov a učitel'om vytvorených úloh a diskusie. V diskusii môže učitel' komunikovat' hromadne alebo jednotlivo so študentami, žiak však môže reagovat' len na učitel’a, nie na spolužiaka.

Študentské prostredie (obr. 2) sa líši v hlavnej lište. Pozostáva z hlavného panelu, mojej skupiny, aby žiak videl spolužiakov, vybavenia oblečenia, zvierat, úloh a diskusie.

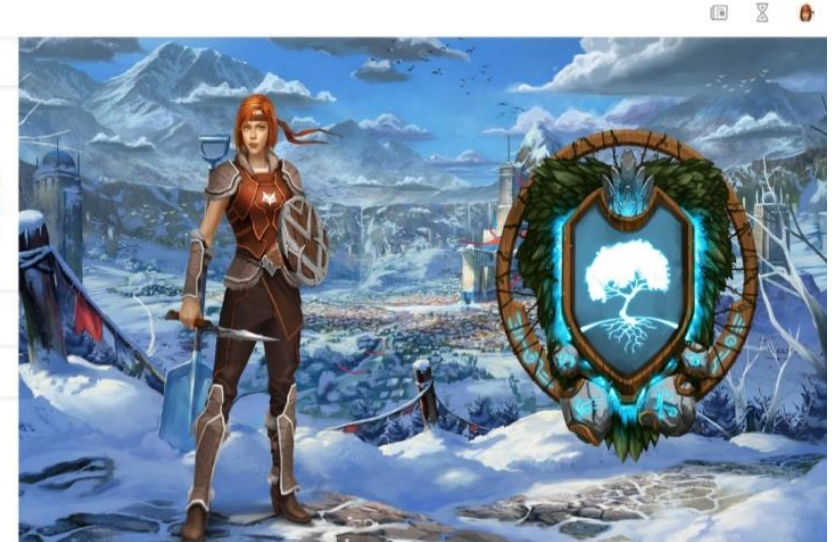

Obrázok 2 Študentské prostredie Classcraft

\subsection{Vplyv Classcraft na vyučovanie na iných školách}

Najviac používatel'ov využívajúcich Classcraft na vyučovacích hodinách je z USA (61 \%), Kanady (13\%), Austrálie (7 \%) a ostatných krajín (19 \%) (Sanchez et al., 2017). Spoločnost' Classcraft uvádza, že podl’a ich dotazníkov s 875 respondentmi, u 98 \% študentoch sa zaznamenal zvýšený záujem, $99 \%$ povedalo, že Classcraft mal pozitívny vplyv na správanie v triede, $88 \%$ študentov sa zlepšilo v prospechu a $89 \%$ učitel'ov si myslí, že ich hodiny sú efektívnejšie (Classcraft Studios Inc., 2019). Classcraft sa radí medzi komplexné gamifikované systémy na rozdiel od jednoduchých, ako napr. Duolingo či Khan Academy (Damsa a Fromann, 2017).

$\mathrm{Na}$ školách vplyvom systému Classcraft vzrástla motivácia rozvíjat' zručnosti 21. storočia (Mustafa, 2018). Učitelia tvrdia, že ich študenti sa zlepšili aj $\mathrm{v}$ technických zručnostiach, komunikácii a time-managemente (Watson, 2018).

\section{Použité metódy}

Zavedenie systému Classcraft prebehlo na Základnej škole s materskou školou Jána Bakossa, Bakossova 5, Banská Bystrica. Ide o štátnu základnú školu, ktorá v rámci Ineko hodnotenia (Ineko, 2018) dosiahla úroveň 4,9, čo predstavuje na škále $0-10$ školu s priemernými výsledkami žiakov 
spomedzi slovenských škôl. Táto škola bola vybratá na základe toho, že v nej autor participuje ako učitel' informatiky. Implementácia systému Classcraft prebiehala na hodinách informatiky, čo predstavuje 1 vyučovaciu hodinu 1krát do týždňa vo všetkých skupinách.

\subsection{Participanti}

V školskom roku 2017/2018 sme Classcraft zaviedli pilotne, zapojili sme len 1 skupinu - 5.A, ktorá pozostávala zo 16 žiakov.

V nasledujúcom školskom roku 2018/2019 boli zapojené viaceré skupiny snažili sme sa zapojit' všetky skupiny, kde sme učili - teda dokopy 3 triedy pozostávajúce zo 6 skupín. Ked’že išlo o platenú verziu na celý rok, 2 žiaci si konto nezakúpili. Spolu sa však zúčastnilo 64 žiakov (obr. 3).

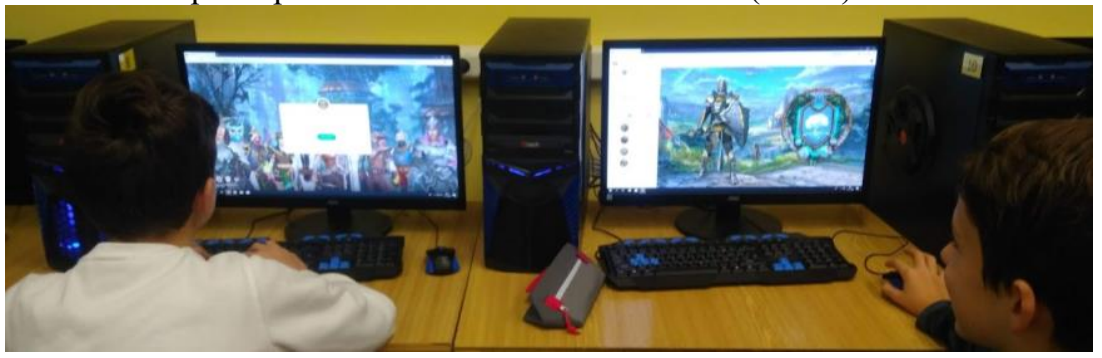

Obrázok 3. Participanti

\subsection{Pilotné skúsenosti so systémom Classcraft v šk. roku 2017/2018}

Všetkým žiakom sa v školskom roku 2017/2018 vytvorilo vlastné konto, nakol'ko pilotná implementácia Classcraft trvá na 1 mesiac zadarmo, po nezakúpení licencie po 1 mesiaci dochádza k obmedzeniu niektorých funkcionalít, napr. analýza študentov, domácich miláčikov, skupinových nástrojov a d’alšie. To, čo je prístupné zadarmo na dobu neurčitú, je triedny management - teda pridávanie bodov - a modifikácia vzhl'adu avatara. Pravidelne sme pracovali s Classcraft od januára 2017 do apríla 2018, neskôr - po obmedzení funkcionalít - už len vel'mi sporadicky. Nám ako učitel'ovi chýbali skupinové nástroje, žiaci boli sklamaní z toho, že si už nemôžu „cvičit“ domácich miláčikov. Na základe diskusie sme sa dohodli, že sa nám Classcraft páči a v budúcom školskom roku si ho zakúpime.

\subsubsection{Prípadová štúdia}

Vytvorili sme úlohu. Ciel’om hodiny bolo, aby sa žiaci naučili vytvárat' vizitky v Microsoft Word. Svet pozostával z 8 menších úloh. Tie sú rozmiestnené po svete, ktorý si učitel' vyberie na základe viacerých možností. Žiaci nadobudnú pocit, že sa prechádzajú svetom, kým plnia jednotlivé úlohy. Posledná úloha je strategicky umiestnená na vrchol najvyššej hory (obr. 4). Žiaci si úlohu prečítajú, prepnú sa do okna MS Word a následne v ňom vypracujú úlohu. V̌setky úlohy (tab. 1) sú robené v rovnakom duchu prostredníctvom príbehu:

\section{Tabul'ka 1. Zoznam úloh k svetu Vytváranie vizitky}




\begin{tabular}{|c|c|c|}
\hline с̌. & Názov úlohy & Úloha \\
\hline 1 & Šéf firmy & $\begin{array}{l}\text { Ahoj, si šéf firmy Bakoša a ideš na stretnutie s inými } \\
\text { šéfmi firiem z Banskej Bystrice. Potrebuješ však vizitku. } \\
\text { Túto hodinu sa naučíme vytvárat' vizitky! }\end{array}$ \\
\hline 2 & $\begin{array}{l}\text { Rozloženie } \\
\text { okraja }\end{array}$ & $\begin{array}{l}\text { Vel'kí šéfovia by takúto prácu zadali svojim } \\
\text { zamestnancom. Všetci tvoji zamestnanci dostali chrípku } \\
\text { a neprídu do roboty. Stretnutie je už zajtra. Je to na tebe! }\end{array}$ \\
\hline 3 & Tvoje údaje & $\begin{array}{l}\text { Doplň vpravo dole do vizitky: meno firmy, meno a } \\
\text { priezvisko, ulica firmy, mesto a PSČ }\end{array}$ \\
\hline 4 & $\begin{array}{l}\text { Písanie vl'avo } \\
\text { hore }\end{array}$ & $\begin{array}{l}\text { Vl'avo hore si napíšs, čo robíš vo svojej firme. Ani šéf } \\
\text { nemôže mat' v práci vyložené nohy! Čo robia vo firmách } \\
\text { šéfovia? }\end{array}$ \\
\hline 5 & Obrázok & $\begin{array}{l}\text { Tvoja vizitka je dost' nudná. Koho by zaujal len kúsok } \\
\text { textu? Vlož do vizitky obrázok z internetu (klikneš na } \\
\text { obrázok - Kopírovat', vo svojej vizitke - Vložit') }\end{array}$ \\
\hline 6 & $\begin{array}{l}\text { Zmena typu } \\
\text { písma }\end{array}$ & $\begin{array}{l}\text { Zmeň písmo tak, aby bolo čo najkrajšie a } \\
\text { najčitatel'nejšie. Môžeš zmenit' farbu a aj vel'kost' písma. } \\
\text { Potrebuješ iných šéfov zaujat! }\end{array}$ \\
\hline 7 & \begin{tabular}{|lr} 
Odkukaj \\
dobré nápady \\
od $\quad$ tvojho \\
tímu \\
\end{tabular} & $\begin{array}{l}\text { Pozrite si v rámci tímu, čo ste vytvorili. Majú tvoji } \\
\text { spolužiaci nápad, ktorý by si mohol použit aj ty? Využi } \\
\text { to, že pracujete v tíme a pomáhajte si. Ste tím! }\end{array}$ \\
\hline 8 & Hurá & $\begin{array}{l}\text { Si pripravený na stretnutie so šéfmi? Skontrolujte si v } \\
\text { tíme vaše vizitky a ohodnot'te ich známkami. Každý dá } \\
\text { známku členovi svojho tímu. Bud’te spravodliví! } \\
\text { Zavolajte pani učitel'ku, ktorá sa o vašich známkach } \\
\text { porozpráva a ked' bude súhlasit', známka je vaša! }\end{array}$ \\
\hline
\end{tabular}

Žiaci boli na začiatku hodiny rozdelení do 4 tímov po $3-4$ vedla seba sediacich žiakov. Už predtým pracovali s MS Word a mali skúsenosti $\mathrm{s}$ rozložením okraja, zarovnaním, vkladaním obrázku, typom písma. Tieto znalosti si mali precvičit' vo vytváraní vlastnej vizitky. Ako určite badat', postup vyhotovenia vizitky je určený v jednotlivých krokoch. Gamifikácia je zahrnutá tak, aby mali žiaci pocit, že sú „šéfovia firiem“, ktorým ochoreli zamestnanci, a teda si musia vizitku vytvorit' sami. Žiaci sa pocitu byt' „š́fom“ vel’mi potešili, najmä chlapci. Ako problém však žiaci videli to, že mali dopredu zadané meno firmy (Bakoša), tak sme sa rozhodli, že si ho môžu vymysliet' sami. Z pozorovania možno usúdit', že sa im to páčilo, niektorí žiaci mali vymyslené názvy firiem hned', niektorým to trvalo aj niekol'ko minút, pretože sa snažili o niečo originálne. Pár žiakom sme museli pomôct', pretože tvrdili, že im nič nenapadá. Následne splnili úlohy spojené s formátovaním tak, aby dostali výsledný produkt: vizitku. Aby sa podporila kolaborácia, mali si pozriet', aké vizitky a prvky v nej použili ostatní spolužiaci - a inšpirovat' sa. Snahou bolo nevytvorit' tzv. konkurenčné prostredie, ale kolaborujúce. Inšpiráciou sa väčšinou stali iné - pre žiakov krajšie - typy písma, príp. názvy firiem, napr. Požičovňa dronov. 
Poslednou úlohou bolo, aby si žiaci v rámci tímu vzájomne oznámkovali vizitky. Pridali sme podmienku, že učitel' musí so známkou súhlasit', aby sa nestalo, že žiaci to zneužijú a niekomu, kto im nie je sympatický, zhoršia známku, príp. naopak. Výsledkom však bolo 13 jednotiek, teda všetci dostali jednotku.

Z reflexie na konci hodiny vyplynulo, že žiakom sa hodina páčila - čiastočne mohli byt' motivovaní aj tým, že pred reflexiou dostali jednotky.

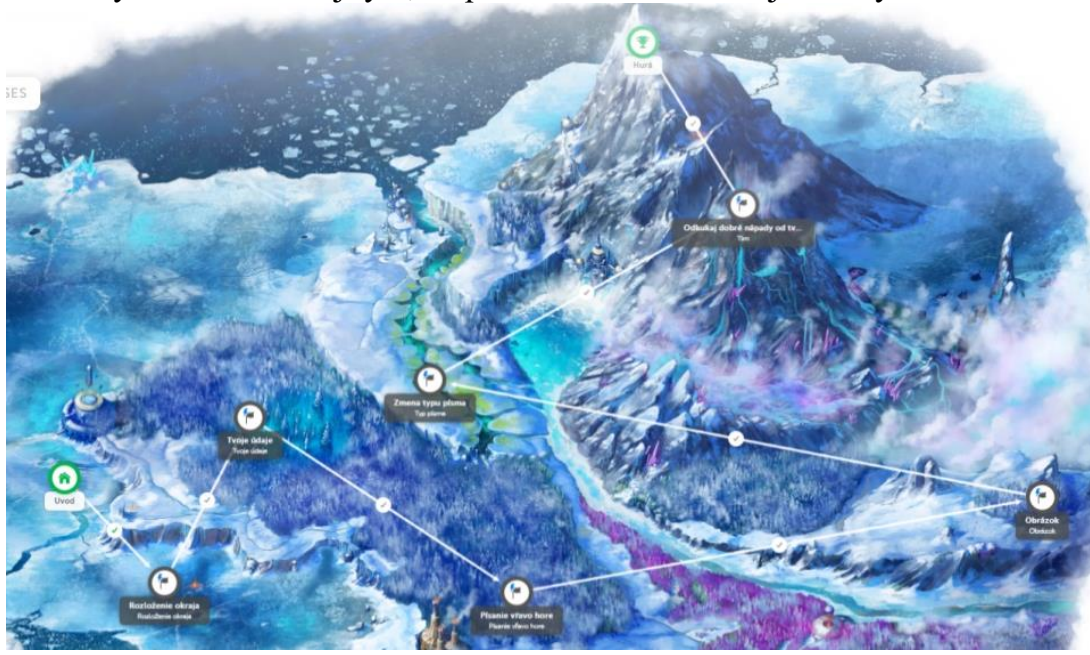

Obrázok 4. Svet Vytváranie vizitky

\subsubsection{Prípadová štúdia}

Práca so skupinovými nástrojmi je primárne určená na posilnenie gamifikácie. V praxi sa nám niektoré nástroje osvedčili a ich používanie sme opakovali na viacerých hodinách, iné sa nám nezdali byt' také nápomocné, príp. sme niektoré vôbec nevyužili.

Koleso osudu vyberá náhodného žiaka alebo tím. Tento nástroj sme použili viackrát na vyvolanie žiaka. V praxi je pre učitel'a niekedy výhodné „zbavit' sa zodpovednosti“ za vyvolávanie žiaka, napr. pri typickej situácii ako je zanesenie triednej knihy do inej skupiny. Často sme počúvali, že ,ja som sa prihlásil prvý“ a „on bol už minule.“ Takto žiaci vedia, že nerozhoduje učitel', ale počítač a nedochádza k takýmto poznámkam. To isté platí aj pri zotieraní tabule a ostatných bežných úkonoch.

Varnovi Jazdci predstavujú sadu náhodných udalostí (tab. 2), pri ktorých sa vyberie práve jedna. Ciel'om je oživit' a vniest' humor do vyučovacieho procesu, náhodné udalosti sa navyše dajú učitel'om modifikovat'. Medzi už vytvorené náhodné udalosti patrí napr.:

Tabul'ka 2. Ukážka náhodných udalostí

\begin{tabular}{|l|l|l|}
\hline Názov & Popis & Dôsledok \\
\hline
\end{tabular}




\begin{tabular}{|c|c|c|}
\hline $\begin{array}{l}\text { Dvoranské } \\
\text { spôsoby }\end{array}$ & $\begin{array}{l}\text { Trénuješ } \quad \text { na } \\
\text { král'ovu návštevu. }\end{array}$ & $\begin{array}{l}\text { Všetci sa musia pri rozhovore navzájom } \\
\text { oslovovat’ ako „milostivý pán“ a } \\
\text { „milostivá pani“. }\end{array}$ \\
\hline $\begin{array}{l}\text { Darček } \\
\text { strážcu }\end{array}$ & $\begin{array}{l}\text { Dnes je tvoj } \\
\text { štastný deň! }\end{array}$ & Jeden náhodný hráč: +1000 XP \\
\hline $\begin{array}{l}\text { Nápoj } \\
\text { premeny }\end{array}$ & $\begin{array}{l}\text { Vypil si nápoj, ale } \\
\text { mal si si najprv } \\
\text { prečítat' etiketu! }\end{array}$ & $\begin{array}{l}\text { Jeden náhodný hráč: skupina musí } \\
\text { oslovovat' náhodného hráča "motýl" } \\
\text { počas celej hodiny! }\end{array}$ \\
\hline $\begin{array}{l}\text { Súboj } \\
\text { šampiónov }\end{array}$ & $\begin{array}{l}\text { Žiarlivý rytier } \\
\text { napadol } \\
\text { najsilnejšieho } \quad \mathrm{Z} \\
\text { vás. }\end{array}$ & Hráč s najviac XP: -20 HP \\
\hline
\end{tabular}

Tento nástroj sme využili viackrát, ale tým, že sme nikdy nevedeli, či udalost' bude dobrá alebo zlá a učitel' to nemohol ovplyvnit', tento nástroj sme často nepoužívali. Raz vyšla udalost', že všetci máme hovorit' pirátskym prízvukom a žiaci povedali, že to robit' nebudú, lebo ich to nebaví. Ciel'om bolo vniest' zábavu, čo sa $v$ tomto prípade nedosiahlo. Možným riešením by mohlo byt', ak by si žiaci v budúcnosti sami navrhli udalosti a reakcie, ktoré by pre nich boli zábavné.

Súboje so šéfom (obr. 5) slúžia na zopakovanie učiva pomocou otázok. Spomedzi žiakov sa náhodne vyberie žiak, ktorý odpovie na otázku. Ak odpovie správne, dostane body a „porazi“ šéfa (počítač v úlohe nepriatela). Ak odpovie nesprávne, body sa mu odpočítajú. My sme tento nástroj použili na zopakovanie MS Word. Otázky boli typu:

- Aká firma vymyslela Word?

- Dá sa vo Worde pracovat's obrázkami?

- $\quad$ Akú ikonu má Word?

Otázka č.2 z 5

$-10 \mathrm{HP}^{\times}$

Aká firma vymyslela Word?

1 Windows

3 Datalan
2 Microsoft

4 Apple

\section{ODHALITT ODPOVED́}

Obrázok 5. Ukážka zadanej otázky v Súboji šéfov

Nástroj žiakov bavil, pretože na konci vyhrali žiaci a nie šéf. Spoločne sa $\mathrm{z}$ toho tešili.

Biela hora znamená odpočítavanie, kde učitel' nastaví čas, ktorý sa bude odpočítavat'. Nám sa tento nástroj osvedčil pri individuálnej práci, kedy 
učitel' na plátno premieta časovač a nemusí žiakom hovorit', kol'ko minút má ešte $\mathrm{k}$ dispozícii.

Beh lesom sú stopky, ktoré sme však nepoužili na vyučovacom procese. Predstavujú opak Bielej hory.

Údolie Makus (obr. 6) je merač hlasitosti. Tento nástroj nás ako učitel'a oslovil najviac. Pri prvej implementácii sme ukázali žiakom na premietacie plátno, ako funguje merač hlasitosti - nech sú čo najtichšie, aby fialový ukazovatel' bol na minime, a potom čo najhlasnejšie, aby bol na maxime. Maximum sme nedosiahli, za to pri tomto nástroji sa trieda vždy utíšila. Dá sa tu nastavit', aké obdobie majú byt' ticho, či hranicu, ktorú nemôžu prekročit' a dá sa aj počas merania aktuálne posúvat'. Po uplynutí času sa žiakom prirátava počet bodov, ktoré určí učitel', po prekročení hranice sa žiakom body uberajú. Toto vždy platí na všetkých žiakov v triede a zároveň aj učitel' musí hranicu hlasitosti dodržiavat'. Na fungovanie je potrebné, aby bol zapojený mikrofón.

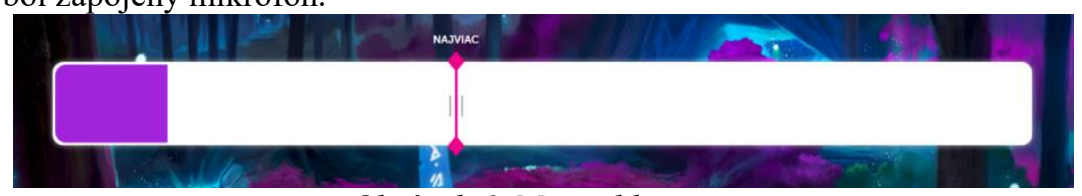

Obrázok 6. Merač hlasitosti

Poklad Tavurosy je klasifikačná kniha, kde sa žiaci môžu hodnotit'. Tento nástroj sme nevyužili, používame papierovú klasifikačnú knihu.

\subsubsection{Výsledky $v$ školskom roku 2017/2018}

V reflexii na Classcraft vyplynulo, že sa nám - učitel'ovi a žiakom - páči

Classcraft a chceli by sme pokračovat', avšak obmedzená funkcionalita nám nevyhovuje a tým sa znižovala naša motivácia implementácie Classcraft do vyučovacieho procesu.

\subsection{Skúsenosti so systémom Classcraft v šk. roku 2018/2019}

V školskom roku 2018/2019 sa zapojilo 64 žiakov zo 6. a 8. ročníka (tab. 3):

Tabul'ka 3. Počet vytvorených kont v pomere $k$ počtu žiakov

\begin{tabular}{|l|l|l|l|}
\hline & $\begin{array}{l}\text { počet } \\
\text { žiakov }\end{array}$ & $\begin{array}{l}\text { počet } \\
\text { vytvorených } \\
\text { kont }\end{array}$ & $\%$ \\
\hline 6.A (1. skupina) & 13 & 11 & 84.62 \\
\hline 6.A (2. skupina) & 13 & 13 & 100 \\
\hline 8.A (1. skupina) & 10 & 10 & 100 \\
\hline 8.A (2. skupina) & 10 & 10 & 100 \\
\hline 8.B (1. skupina) & 10 & 10 & 100 \\
\hline 8.B (2. skupina) & 10 & 10 & 100 \\
\hline
\end{tabular}

6. ročník mal skúsenosti s Classcraft už minulý rok, 8. ročník o ňom len počul $\mathrm{z}$ nášho rozprávania a ukázania promo videa. Cena Classcraft = 
licencia je viazaná na učitel'a, teda za hlavné konto platí učitel', ktorý má neobmedzené množstvo tvorby tried, skupín a počtu žiakov.

\subsubsection{Prípadová štúdia}

$\mathrm{V}$ tomto školskom roku sme úlohy nevyužívali priamo na vyučovacom procese, ale skôr ako doplnok k nemu - nazvali sme to domáce úlohy, ktoré však boli dobrovol'né - za splnenie mali žiaci body a ich avatar sa zlepšoval, za nesplnenie nebola žiadna sankcia. Aby sme podporili gamifikáciu, nazvali sme úlohy tajnými misiami.

Prázdninová tajná misia pre 6. a 8. ročník bola nastavená na orientáciu sa v úlohách a prostredí Classcraft - aby sa doma dopracovali do diskusie pre danú úlohu a aby vedeli postupovat' do vyšších kôl. Táto úloha pozostávala zo 4 častí, kde hlavnou úlohou bolo: „Tvojou úlohou je spravit’ dobrý skutok - to znamená, že napríklad niekomu pomôžeš. Pozor, nezabúdaj na to, že je to tajné! Žiadne také, že "mamíííí, idem ti pomôct' umyt' riad, lebo mám prísne tajnú misiu z informatiky!" Poviem ti tajomstvo - za dobrý skutok ti dám d'alšie body! Ešte stále si nikomu nepomohol? No teda, na čo čakáš?? Nezabudni do skupinovej diskusie napísat, aký dobrý skutok si spravil - kto tak neurobí, body nebudú prirátané.“

Väčšina žiakov sa do misie zapojila, našli aj diskusiu na danú úlohu a ich odpovede boli:

- Pomáhal som st'ahovat' babke skrine.

- Umyla som riad, povysávala som.

- Šla som do školy, pomohla som mamke zbavit' sa ma.

- Ja som vytriedila odpad, včera som povysávala, sestre som pomohla vyčistit akvárium s myšami a dnes som Sophi pomohla zaregistrovat' sa.

Prázdninová tajná misia mala taký úspech, že na hodine informatiky si žiaci pýtali d'alšie tajné misie.

2. tajná misia sa v 8. ročníku zameriavala na vytvorenie tabul'ky v MS Word. Chceli sme podporit' aj ich kreatívne myslenie, preto sa svet nachádzal v podzemných chodbách.

Svetu sme prispôsobili príbeh. Prvá úloha (tab. 4) znela „Všimli ste si na mape, v akom prostredí sa nachádzate? Sú to rôzne podzemné chodby. Kto tam asi môže bývat? Aký je? Čo robí?“' Odpovede boli vskutku zaujímavé: 


\begin{tabular}{|c|c|}
\hline $\begin{array}{l}\text { Snuffleball... } \\
\text { Má citlivý čuch, rád sa hrá a je } \\
\text { priatel'ský. Vždy ked môže tak } \\
\text { pomáha. Nemá rád svetlo a hluk. } \\
\text { Vyzerá ako velká tmavá chlpatá } \\
\text { gulla. Na prvý pohl'ad môže byt' aj } \\
\text { desivý, ale naozaj nieje. :) }\end{array}$ & MENO : Čupakabra JE : Ruzový RÁD : Spí \\
\hline $\begin{array}{l}\text { Meno: Greenwall } \\
\text { Aký je: je mily, zabavný, } \\
\text { pracovitý,miluje vôñu trávý po daždi } \\
\text { Čo robí: rád sa hrá so svojimi } \\
\text { zvieracimi kamaratmi, pomaha } \\
\text { veveričkam zbierat' potravu, stavá } \\
\text { vtáčikom hniezda, ked nepomaha } \\
\text { zvieratam tak vari alebo pečie, } \\
\text { najradšej pečie šiškový koláč s jeho } \\
\text { tajnou ingredienciou }\end{array}$ & $\begin{array}{l}\text { Chlpáč- Podobá sa na myš, ale nie je to myš, podobá sa na } \\
\text { chameleóna, ale nie je to chameleón. } \\
\left(\begin{array}{c}\odot \\
\text { "posledným dñom" zjedli syr. }\end{array}\right.\end{array}$ \\
\hline $\begin{array}{l}\text { Podzemníci } \\
\text { Vedia lahko vedia vykopat' tunely a } \\
\text { vel'mi dobre vidia } v \text { tme podobajú sa } \\
\text { na vel'kých krtkov }\end{array}$ & $\begin{array}{l}\text { Môj tvor sa volá Derty. Býva sám ale len občas s priatelimi. } \\
\text { Rád sa bicykluje ale nemá naohy a tak si zostrojil bicykel s } \\
\text { motorom a šlape rukami. Má vela kamarátov. }\end{array}$ \\
\hline
\end{tabular}

Druhá úloha (tab. 5) znela: „Každá úloha potrebuje dobrý plán. Najlepšie je rozdelit' si vel'ký problém na menšie problémy a hned' pôjde všetko l'ahšie! Napíšte svojmu tvorovi podrobný plán - tabul'ku s 10 riadkami, čo má robit' cez deň. Pozor, všetci tvorovia sa nejako podiel'ajú na tom, aby sa postavil rebrík. Zadanie vypracujte vo Worde, kde vytvoríte tabul'ku s 2 stĺpcami a 10 aktivitami. Dokument uložte u seba v počítači a nahrajte do zadania.“

Odovzdaní bolo už menej, za najlepšie vyberáme nasledujúce:

\section{Tabul'ka 5. Žiacke vypracovanie úlohy}

\begin{tabular}{|l|l|}
\hline C. aktivity & Aktivita: \\
\hline 1 & Chlpáča zobudí pani Chlpáčová \\
\hline 2 & Chlpáč pripraví svojím det'om vyprážaného cvrčka \\
\hline 3 & $\begin{array}{l}\text { Chlpáč nasa dne na zotročeného lúčneho koníka a odskáče za jeho kamarátkou } \\
\text { Stračicou }\end{array}$ \\
\hline 4 & Chlpáč sa spýta Stračice, či jej nezostali zvyšné konáre zo stavby hniezda \\
\hline 5 & Chlpáč si zo Sračiciných konárov postavý fúnk \\
\hline 6 & Chlpáč príde za jeho kamarátmi, ktorí mu mali zohnat drevo \\
\hline 7 & Chlpáč fúrikom zoberie drevo na stavenisko \\
\hline 8 & Na stavenisku ho vyloži pred Alfom, ktorý spolu s Chlpáčom postayý rebrik \\
\hline 10 & Všetci tvorovia založia rebrík do hlinených základov \\
\hline
\end{tabular}

3. tajná misia bola určená pre chlapčenskú skupinu v 8.A. Zistili, že im chýba niekol'ko bodov do novej úrovne, a tak by si mohli graficky vylepšit' avatara. Ked’že išlo o spontánnost' a začali sme preberat' MS Excel, za úlohu dostali vytvorit' rozvrh hodín - nevypracovali sme žiadny príbeh, bola 
stanovená len úloha. Žiaci samozrejme úlohu vypracovali, nahrali na Classcraft a body dostali.

4. tajná misia sa zameriavala hlavne na reflexiu z hodiny, počas ktorej sme pracovali s micro:bit. Ked’že ide o misiu, ktorá bola zverejnená len pred pár dňami, obdržali sme zatial' len 1 odpoved'. V prvej úlohe sme sa pýtali, aký majú žiaci názor na micro:bit: „Ked’ som držala micro:bit prvýkrát, nevedela som, čo sa s ním robí, takže som si ani nič nemyslela. Vel'mi ma prekvapilo, čo taká malá vec dokáže a určite by som s ním ešte chcela pracovat'." Ako d'alšiu úlohu sme uverejnili linky na sút'až $\mathrm{s}$ micro:bit a editor na programovanie. Poslednou úlohou - prekvapením - bol odkaz na videodokument, kde sú ukážky toho, ako deti chodia do školy z rôznych kútov sveta, napr. v Afrike cez púšt', v Indii sa brodia riekou atd'. Úlohou bolo napísat' do diskusie, čo majú naši žiaci spoločné a rozdielne s týmito det'mi. Na úlohu zatial' neodpovedali.

\section{Záver}

V článku sme sa zamerali na gamifikáciu a implementáciu Classcraftu do edukačného procesu. Na základe skúsenosti so žiakmi 5., 6., 8. ročníka možno usúdit', že Classcraft dokáže motivovat' žiakov, ale len v prípade, že je plne funkčný, teda v platenej verzii. Posúdili sme rôzne funkcionality, niektoré aktívne využívame $\mathrm{v}$ edukačnom procese, niektoré nevyužívame, pretože sa podl'a nás netýkajú ciel'ov hodiny vyučovania informatiky. Je na učitel'ovom uvážení, ktoré funkcionality využije, ale apelujeme na to, aby funkcie smerovali kriticky k ciel'om vyučovania, pretože sa môže stat', že ak sa Classcraft stane „hlavnou témou“, nemusí byt' ciel' hodiny splnený. Classcraft ako podporný prostriedok na motiváciu u študentov v rámci vyučovania alebo aj mimo školy vrelo odporúčame.

Tento príspevok vznikol za podpory grantovej agentúry APVV v rámci riešenia projektu 15-0368 Prax v centre odborovej didaktiky, odborová didaktika v Centre praktickej prípravy.

\section{Bibliographic references}

CLASSCRAFT STUDIOS INC. 2019. Classcraft. Available online: https://www.classcraft.com/sk/.

DAMSA, A. - FROMANN, R. 2017. Gamification and Gameful Approaches in Education, Business, and IT. Informatika. Vol. 15. No. 1.

INEKO. 2018. Available online: http://skoly.ineko.sk/skola/?ID=2129.

JARABEK, J. 2013. Aplikacia pre zaznam nalady s prvkami gamifikacie pre android. Brno.

MICHALICKOVA, V. - LOVASZOVA, G. 2014. Fostering Higher-Order Thinking Skills within an Online Learning Environment. DIVAI 2014 The 10th International Scientific Conference on Distance Learning in Applied Informatics. pp. 411-420.

MUSTAFA, H. 2018. A research project submitted for the Master of Arts in Learning and Teaching Programme. London. 
SANCHEZ, E. et al. 2017. Classcraft: from gamification to ludicization of classroom management. Education and Information Technologies, 22.2: pp. 497-513.

VRABEC, N. 2010. Digitalni domorodci na Slovensku: komunikacia a nova identita mladeze $\mathrm{v}$ on-line prostredi. Communication today,

WATSON, S. 2018. Motivating Computer Science Students Beyond Classwork with Games and Gamification. Charlotte.

\section{Nika Klimova}

Department of Computer Science

Faculty of Natural Sciences

Constantine the Philosopher University in Nitra

Tr. A. Hlinku 1

94974 Nitra

Slovakia

nika.klimova@ukf.sk 